\title{
Keratin, Type I Cytoskeletal 18
}

National Cancer Institute

\section{Source}

National Cancer Institute. Keratin, Type I Cytoskeletal 18. NCI Thesaurus. Code C111868.

Keratin, type I cytoskeletal 18 (430 aa, $\sim 48 \mathrm{kDa}$ ) is encoded by the human KRT 18 gene.

This protein plays a role in both intermediate filament structure and the inhibition of apoptosis. 